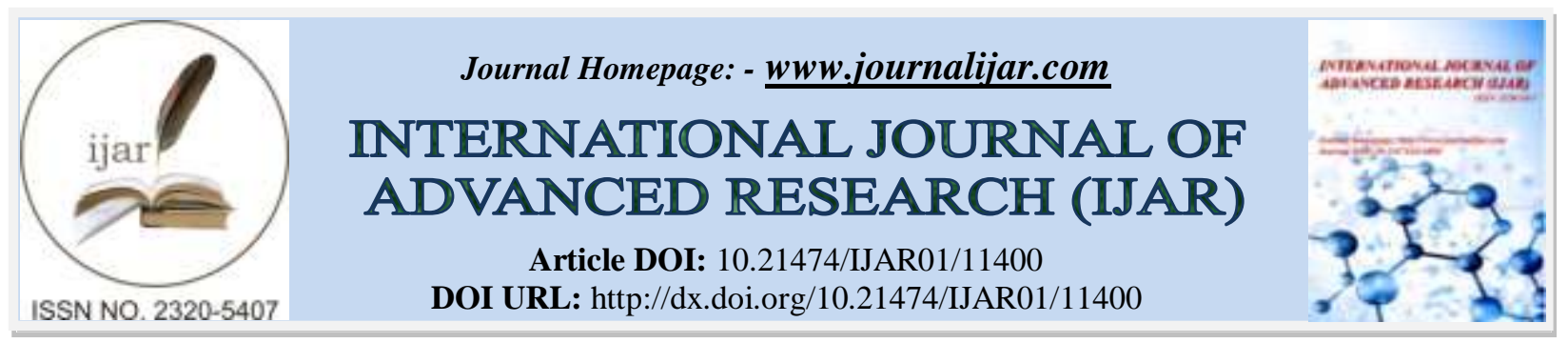

RESEARCH ARTICLE

\title{
AUDIT OF PRIMARY PCI IN AN INDIAN TERTIARY CARE CENTER
}

\author{
Dr. Indraneel Dasgupta ${ }^{1}$, Dr. B. Sathindra Sasmita ${ }^{2}$ and Dr. Neris Dkhar ${ }^{3}$ \\ 1. MRCS (Edinburgh), MRCS (Glasgow), MCEM (U.K.). \\ 2. MBBS,DNB EMERGENCY. \\ 3. MBBS.,MEM.
}

\section{Manuscript Info}

(........................

Manuscript History

Received: 25 May 2020

Final Accepted: 28 June 2020

Published: July 2020

\section{Abstract}

Our audit titled "Primary Percutaneous Coronary Intervention in an Indian Tertiary Care Centre" was conducted to assess the time taken for primary PCI for the patients presenting with chest pain to our hospital. The study was conducted in a tertiary care centre "Peerless Hopsital and B.K.Roy research centre" Kolkata, India. The sample size for the audit is 72. The study was conducted over a period of 1 year. According to European Society of Cardiology 2017 STEMI guidelines, maximum time from STEMI diagnosis to primary PCI in patients presenting to tertiary care centre should be within 60minutes(1hour) and delay accepted till 120minutes(2hours). From the above study period of 1 year, 29\% of the patients have presented within 6 hours of onset of symptoms and $71 \%$ of patients presented after 6 hours. With this guideline reference, in our audit, we found that $21 \%$ of patients were sent for PCI within 120minutes from the time of diagnosis and $59 \%$ were sent within 6hours. Delay of PCI in some patients was due to patient attendants taking more time to admit the patients. Quick counselling of PCI patients/attendants to be done once PCI is planned to avoid delay. The EMS should be taught to diagnose STEMI before arrival to the hospital and so the time delay can be reduced. Awareness programs should be conducted regarding the early intervention strategy for cardiac patients in the community, which will decrease the arrival time to hospital. 


\section{Table 5 Summary of important time targets}

\begin{tabular}{|c|c|}
\hline Intervals & Time targets \\
\hline Maximum time from FMC to ECG and diagnosis" & $\leq 10$ min \\
\hline $\begin{array}{l}\text { Maximum expected delay from STEMI diagnosis } \\
\text { to primary PCl (Wire crossing) to choose primary } \\
\text { PCl strategy over fibrinolysis (if this target time } \\
\text { cannot be met, consider fibrinolysis) }\end{array}$ & $\leq 120 \mathrm{~min}$ \\
\hline $\begin{array}{l}\text { Maximum time from STEMI diagnosis to wire } \\
\text { crossing in patients presenting at primary PCI } \\
\text { hospitals }\end{array}$ & $\leq 60 \mathrm{~min}$ \\
\hline $\begin{array}{l}\text { Maximum time from STEMI diagnosis to wire } \\
\text { crossing in transferred patients }\end{array}$ & $\leq 90 \mathrm{~min}$ \\
\hline $\begin{array}{l}\text { Maximum time from STEMI diagnosis to bolus or } \\
\text { infusion start of fibrinolysis in patients unable to } \\
\text { meet primary PCl target times }\end{array}$ & $\leq 10$ min \\
\hline $\begin{array}{l}\text { Time delay from start of fibrinolysis to evaluation } \\
\text { of its efficacy (success or failure) }\end{array}$ & $60-90 \mathrm{~min}$ \\
\hline $\begin{array}{l}\text { Time delay from start of fibrinolysis to } \\
\text { angiography (if fibrinolysis is successful) }\end{array}$ & $2-24$ hours \\
\hline
\end{tabular}

$E C G=$ electrocardiogram; $F M C=$ first medical contact; PCI = percutaneous coronary intervention; STEMI = ST-segment elevation myocardial infarction "ECG should be interpreted immediately.

\section{Stemi Guidelines}

\begin{tabular}{|c|c|}
\hline $\begin{array}{l}\text { CHANGE IN RECOMMENDATIONS } \\
2012 \\
2017\end{array}$ & 2017 NEW RECOMMENDATIONS \\
\hline \begin{tabular}{|l|} 
Radial access \\
MATRX' \\
\end{tabular} & $\begin{array}{l}\text { - Additional lipid lowering therapy if LDL }>1.8 \mathrm{mmol} L \mathrm{~L} \\
\text { (70 mg/dL) despite on maximum tolerated statins } \\
\text { MPROVE }\end{array}$ \\
\hline 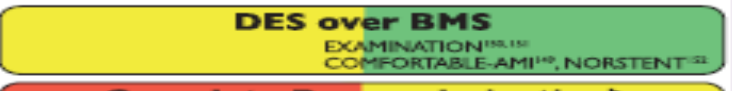 & $\begin{array}{l}\text { - Complete revascularization during index primary } \\
\text { PCI in STEMII patients in shock } \\
\text { Expert opirion. }\end{array}$ \\
\hline 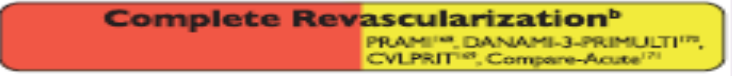 & - Cangrelor if P2Y in inhibicors have not been given \\
\hline $\begin{array}{l}\text { Thrombus Aspiration } \\
\text { TOTAL TASTE' } \\
\end{array}$ & $\begin{array}{l}\text { - Swioch to potene P2Y } 12 \text { inhibicors } 48 \text { hours after fibrinolysis } \\
\text { Expert opinion } \\
\text { - Extend Ticagrelor up to } 36 \text { months in high-risk pationts }\end{array}$ \\
\hline $\begin{array}{l}\text { Bivalirudin } \\
\text { MATRIX, HEATPPCIN }\end{array}$ & $\begin{array}{l}\text { - Use of polypill to increase acherence } \\
\text { FOCUS }\end{array}$ \\
\hline $\begin{array}{l}\text { Enoxaparin } \\
\text { ATOLL }\end{array}$ & $\begin{array}{l}\text { - Routine use of deferred stenting } \\
\text { DANAMI 3-DEFER }\end{array}$ \\
\hline $\begin{array}{c}\text { Early Hospital Discharged } \\
\text { smal tials s observational dacaisosas }\end{array}$ & \\
\hline 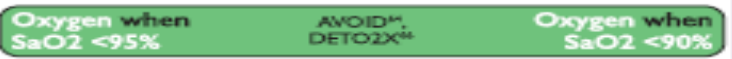 & \\
\hline $\begin{array}{|lrr|}\begin{array}{l}\text { Dose i.V. TNK-tPA } \\
\text { same in all patients }\end{array} \text { STREAMral } & \begin{array}{c}\text { Dose i.V. TNK-tPA } \\
\text { half in Pts } \geq 75 \text { years }\end{array} \\
\end{array}$ & \\
\hline \multicolumn{2}{|c|}{2017 NEW / REVISED CONCEPTS } \\
\hline $\begin{array}{l}\text { MINOCA AND QUALITY INDICATORS: } \\
\text { - New chapters dedicated to these topics. }\end{array}$ & $\begin{array}{l}\text { TIME LIMITS FOR ROUTINE OPENING OF AN IRA? } \\
+0-12 \mathrm{~h} \text { (Class } 1 \text { ): } 12-48 \mathrm{~h} \text { (Class lla): }>48 \mathrm{~h} \text { (Class III). }\end{array}$ \\
\hline \multirow{3}{*}{ 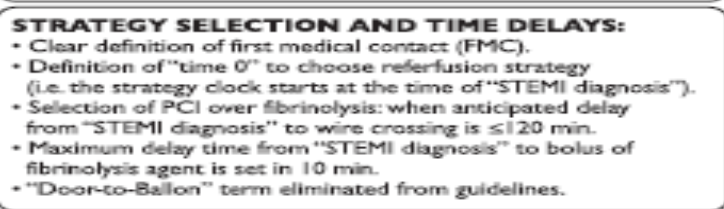 } & $\begin{array}{l}\text { ELECTROCARDIOGRAM AT PRESENTATION: } \\
\text { - Left and right bundle branch block considered equal for } \\
\text { recommending urgern angiograptry if ischemic symptoms. }\end{array}$ \\
\hline & $\begin{array}{l}\text { TIME TO ANGIOGRAPHY AFTER FIBRINOLYSIS: } \\
\text { - Timeframe is set in } 2-24 \mathrm{~h} \text { after swecessful fibrinolysis. }\end{array}$ \\
\hline & $\begin{array}{l}\text { PATIENTS TAKING ANTICOAGULANTS: } \\
\text { - Acute and chronic management presented. }\end{array}$ \\
\hline
\end{tabular}


Figure I What is new in 2017 STEMI Guidelines. BMS = bare metal stent; DES = drug eluting stent IRA = infarct related artery; iv. = intravenous; $\mathrm{LDL}=$ low-density lipoprotein; $\mathrm{PCl}=$ percutaneous coronary intervention; $\mathrm{SaO2}=$ arterial oxygen saturation; $\mathrm{STEMI}=\mathrm{ST}$-elevation myocardial infarction;TNK-tPA = Tenecteplase tissue plasminogen activator. For explanation of trial names, see list of.

${ }^{a}$ Only for experienced radial operators.

${ }^{\mathrm{b}}$ Before hospital discharge (either immediate or staged).

${ }^{c}$ Routine thrombus aspiration (bailout in certain cases may be considered).

${ }^{d}$ In 2012 early discharge was considered after $72 \mathrm{~h}$, in 2017 early discharge is $48-72 \mathrm{~h}$.

e If symptoms or haemodynamic instability IRA should be opened regardless time from symptoms onset.

In left and mid panels, below each recommendation, the most representative trial (acronym and reference) driving the indication is mentioned.

\section{Data Study Period:}

January 2017 - December 2017

\section{Total Population:}

72

\section{Inclusion Criteria:}

Age group 30-80 years, Coronary Angiography done outside without any intervention in patients presenting $<96$ hours.

\section{Exclusion Criteria:}

Age group $<30$ years, received prior fibrinolytic agent, presentation to the hospital $>96$ hours of symptom onset.

\section{Study Site:}

Peerless Hospital and B.K.Roy research centre, Kolkata, India.

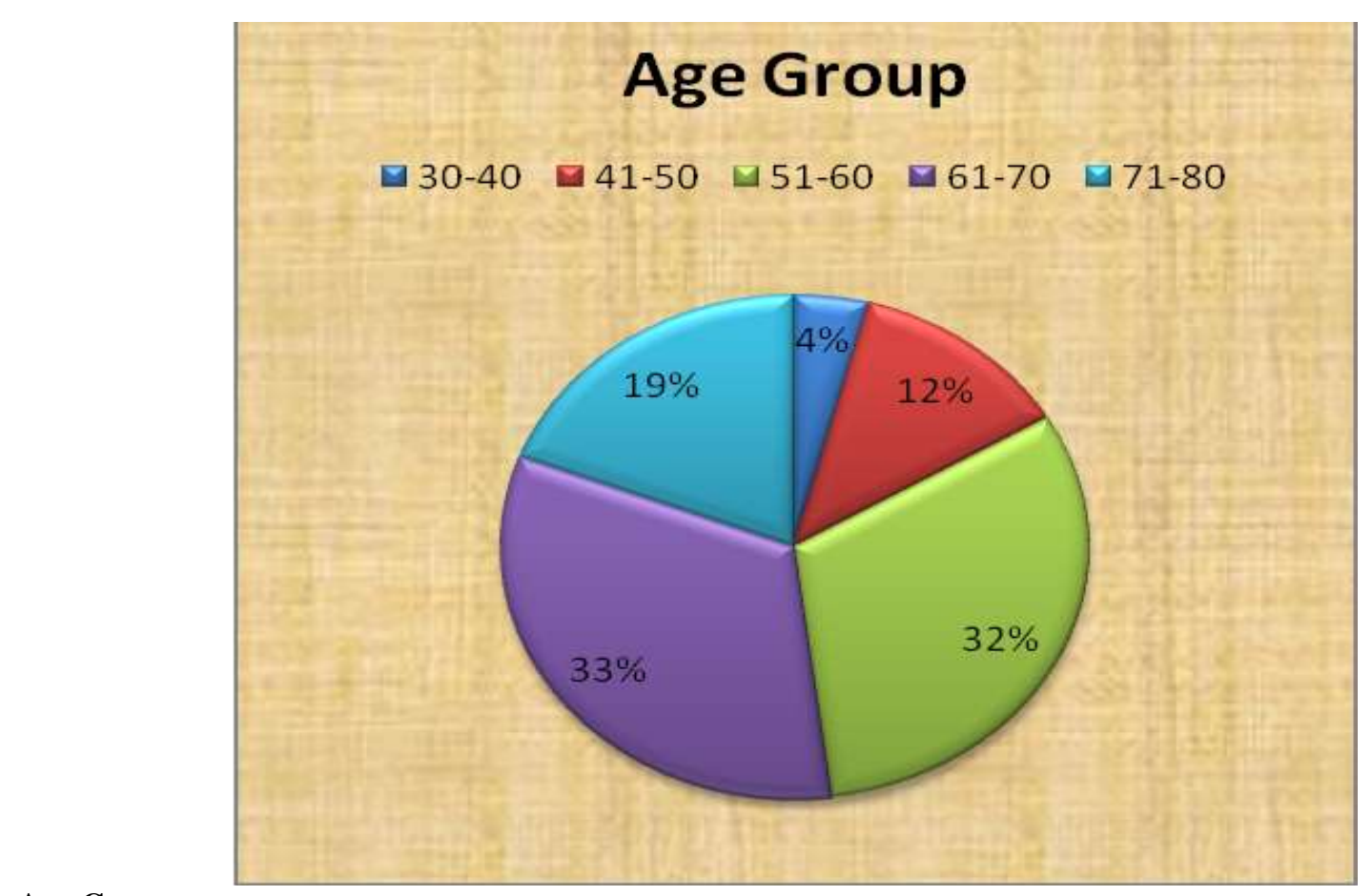

\section{Age Group:}

$30-40-4 \%$

41-50-12\%

51-60 -- 32\%

$61-70-33 \%$

$71-80-19 \%$ 


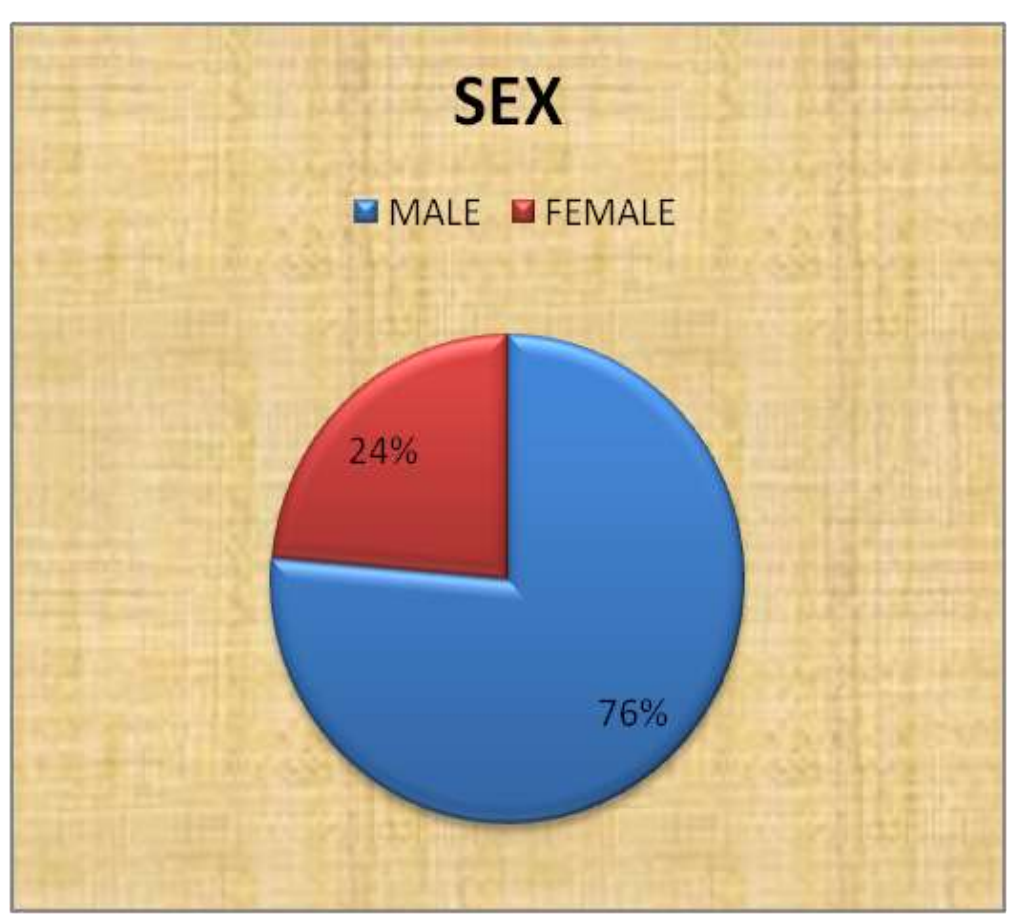

SEX:

Male $-76 \%$

Female $-24 \%$

\section{Comorbidities:}

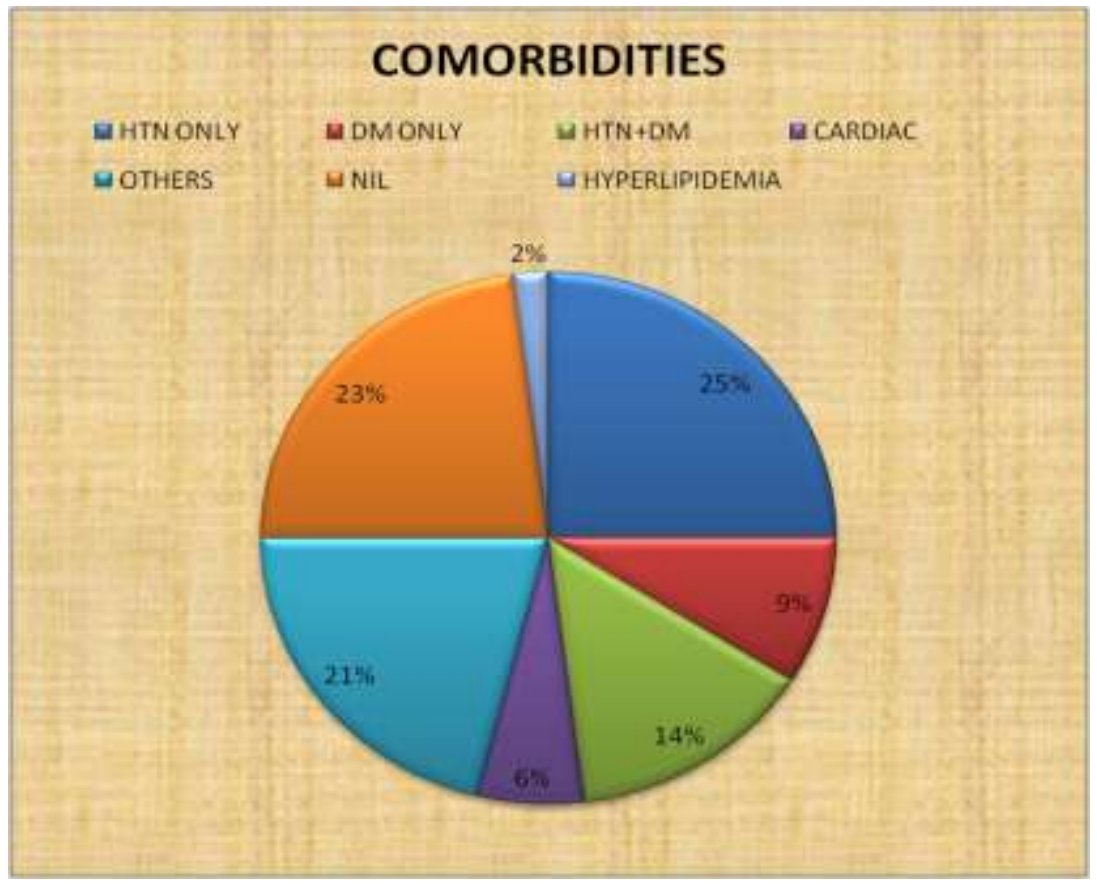

Hypertension - 25\%

Diabetes - 9\%

Hypertension and diabetes $-14 \%$

Previous cardiac $-6 \%$

Others $-21 \%$

Hyperlipidemia - 2\% 
Nil $-23 \%$

Chest pain to hospital arrival:

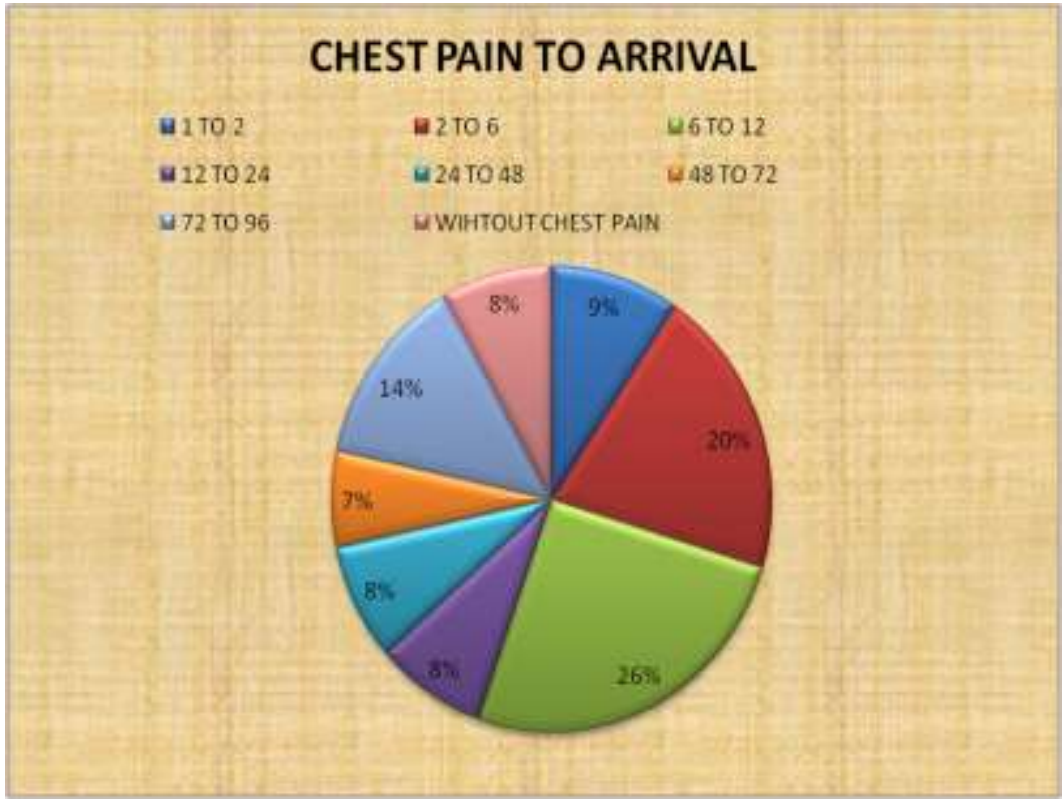

$1-2$ hours $-9 \%$

$2-6$ hours $-20 \%$

$6-12$ hours $-26 \%$

$12-24$ hours $-8 \%$

$24-48$ hours $-8 \%$

$48-72$ hours $-7 \%$

$>72$ hours $-14 \%$

No chest pain $-8 \%$

\section{Routine Medications:}

\section{ROUTINE MEDICATIONS}

$\triangle H T N \square D M \square H Y P E R L I P I M C A D \square O T H E R S \square N I L$

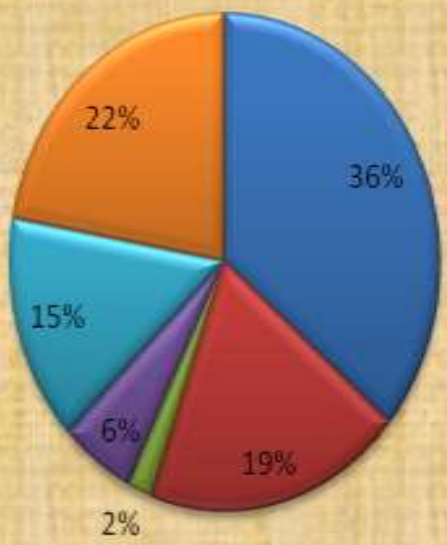

Hypertension - $36 \%$ 
Diabetes - 19\%

Hyperlipidemia - 2\%

Previous cardiac

disorder $-6 \%$

Others- $15 \%$

Nil $-22 \%$

\section{LOADING DOSE}

GRECEIVED G NOTRECEIVED

Loading Dose:

Received $-56 \%$

Not received -- $44 \%$

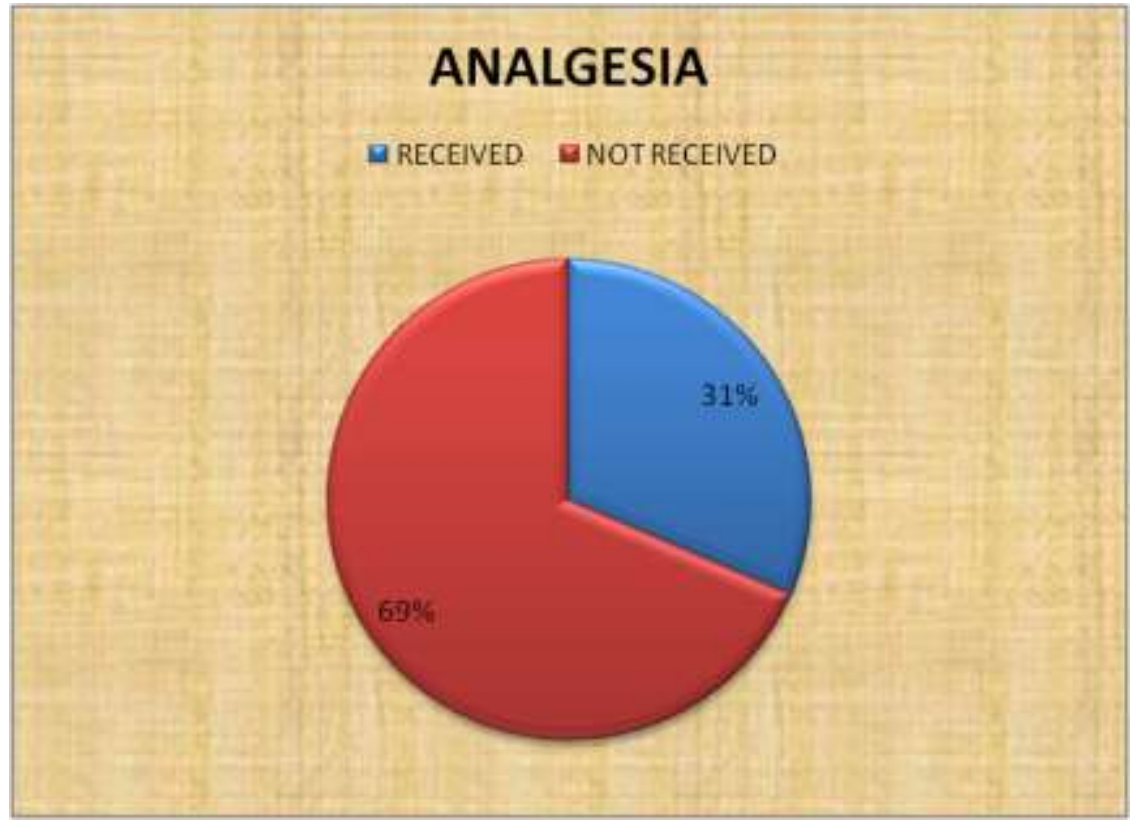

Analgesia:

Received $-31 \%$

Not received $-69 \%$

Door to balloon time: 

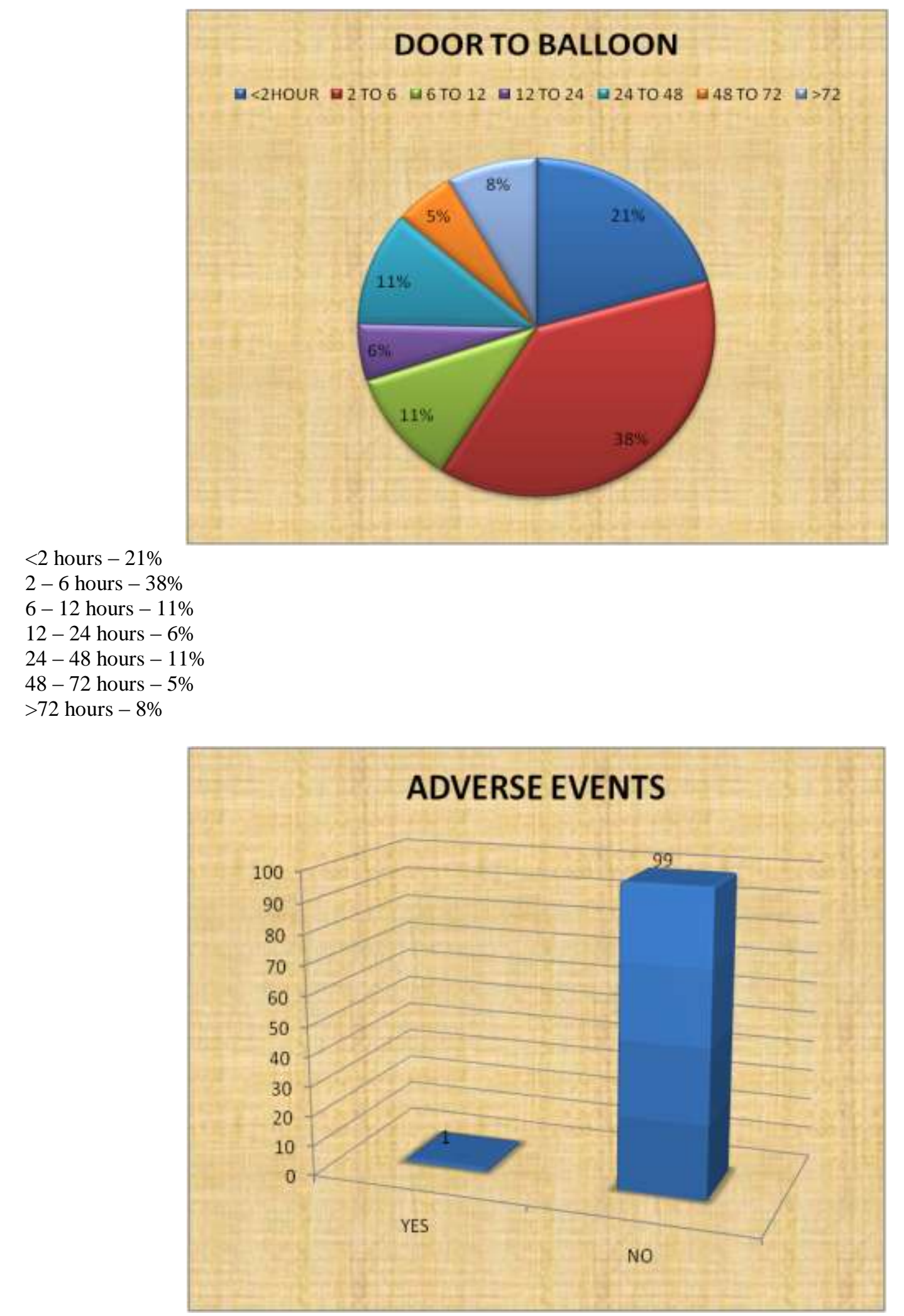

Adverse events:

Nil-99\%

Eventful - 1\% 


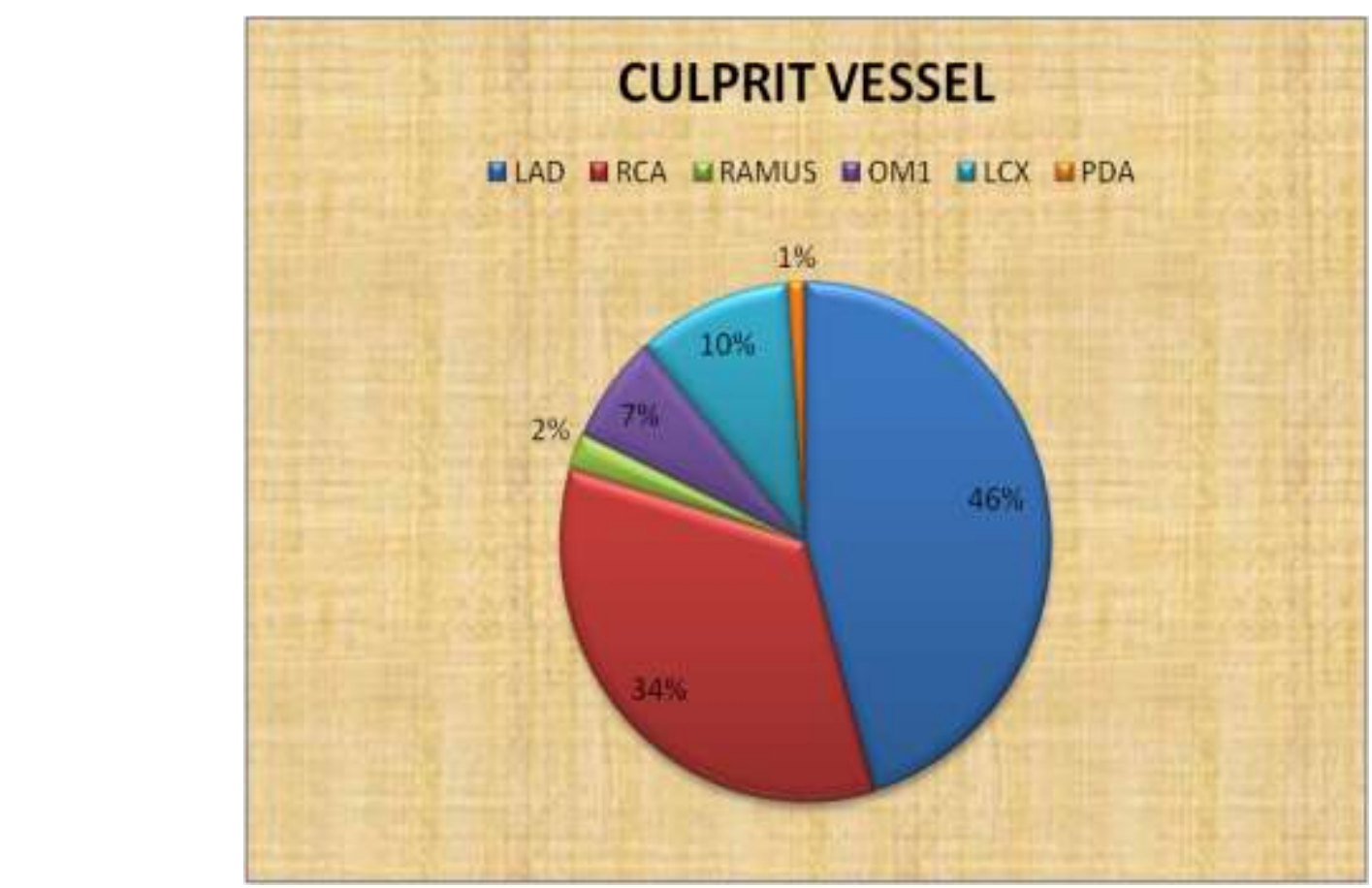

Culprit vessel:

$\mathrm{LAD}-46 \%$

$\mathrm{RCA}-34 \%$

LCX $-10 \%$

OM1 $-7 \%$

RAMUS $-2 \%$

PDA $-1 \%$

\section{Conclusion:-}

From the above study period of 1 year, 29\% of the patients have presented within 6 hours of onset of symptoms and $71 \%$ of patients presented after 6 hours.

Among all the patients, $21 \%$ of patients were sent for PCI within 120minutes from the time of diagnosis and 59\% were sent within 6hours.

99\% of all patients treated with PCI had no adverse events post procedure.

\section{Recommendations:-}

Delay of PCI in some patients was due to patient attendants taking more time to admit the patients. Quick counselling of PCI patients/attendants to be done once PCI is planned to avoid delays.

The EMS should be taught to diagnose STEMI before arrival to the hospital, so the time delay can be reduced.

Awareness programs should be conducted regarding the early intervention strategy for cardiac patients in the community, which will decrease the arrival time to the hospital.

We thank our Head of Department, Dr. Indraneel Dasgupta and our academic director, Dr. Subhrojyoti Bhowmick for encouraging and supporting us throughout the audit.

We would also like to thank the Quality department and the Medical Record department who helped us with the data collection. 